\title{
GUARANTEE IN ISLAMIC LAW PERSPECTIVES: A THEORETICAL DISCUSSION OF FIQH AL-MUQĀRIN/MADHĀHIB COMPARISON
}

\author{
Muhajirin \\ Graduate Student of Islamic Law (S.3) Study Program Sunan Gunung Djati State Islamic \\ University of Bandung and Permanent Lecturer at STAI Al-Hamidiyah Jakarta \\ ibnusyahrustany@gmail.com
}

\begin{abstract}
Guarantee in Islamic Law Perspectives: Guarantee is a system that usually comes in the selling of automotive or electronics product, including others. The reason for this guarantee application for producer is basically to increase the selling rate of one product. While for the consumers this is a form of protection to the item they have purchased. There is indeed a mutualism relationship in this practice. The discussion of the application of guarantee in an Islam Law of trade practice is still being argued whether it is legal or not among the scholars. This happens because of the differences of foundation they use in establishing the legality of guarantee in Islam trade. The definition of guarantee in Indonesia state Law can be found in verse 1316 of Law Book, which is: guarantee is an enclose later from a product saying that the producers ensure a particular product from any worker mistakes and material failure during certain time. The result of this research is the enclosing of Guarantee given in trade as a promise between seller and buyer to ensure the satisfaction of the buyer. The consequence would be to replace the item by justifying its damage.
\end{abstract}

Keywords: Guarantee, Al-Wa'd, and al-Kharāj bi al-Damān.

\section{A. INTRODUCTION}

Running any business will definitely be faced with a business competition (Canavor, 2013, p. 113). To respond the challenges and avoid bankruptcy, business people need a precise strategy to break through the intense competition (Fiore, 2003, p. ix). As the competition gets more complicated in trade and industry, the producers get even more swift in looking for a strategic costumer, of course by formulating more varieties and interesting product offer (Thompson \& Martin, 2005, p. 123). One thing common is the application of trade by guarantee or free service (Gabszewicz, 1999, p. 1). The producers and distributors on the one hand think this system could help the customers in having their rights as costumers (Sigman \& Kieninger, 2009, p. 22) and on the other hand it can help increase the selling rate of one product (Holder, 2016, p. 142). From this introduction, the writer feels necessary to explain the exact law of how to apply guarantee system within a product. 
On the macro perspective, Islam has regulated many kinds of transaction starting from the very first bargain to the form of ownership (Abdul-Rahman, 2014, p. 48), its sole purpose none other than to ensure that no one get cheated (Askari, Iqbal, \& Mirakhor, 2014, p. 35). The meaning of aqad (transaction) in perspective of syara defined as a common form that regulates based on shara' procedure (al-Jurjānī, 1980, p. 153).

In order to increase selling rate in the market and to arouse interest among buyers and to give satisfaction, the producers applied many kinds of strategies so they get as many profits as it can. This kind of pattern of selling attracts customers to choose items with guarantee service. Initially this guarantee given to assure whenever damage happen on the product, all cost of service will be under producers' responsibility (Essid, 1995, p. 61).

\section{B. METHOD}

This research is a qualitative, in which the writers collect the data, analyze and interpret it qualitatively (Bachtiar, 1997, p. 21). Qualitative research commonly gives more focus on the process instead of the product of an object examined (Muhadjir, 2000, p. 43). In other words, this research relies on accurate data collection gained through theoretical study (Bogdan \& Taylor, 1975, p. 4). The data used in this research are taken fully from theoretical study. Data collection done through theoretical study relevant with the topic discussed. Source of data including: books, documents, news papers, magazines, journals and websites containing necessary info. Data collected will be classified based on the content and they will be analyzed further.

The data collection then being analyzed using content analysis technique, which is analyzing the books thoroughly applying a rule - as stated by Noeng - of objective, systematic and generalized. By generalized it means that every finding must have theoretical contribution (Muhadjir, 2000, p. 68).

In the process of data analysis, inductive and deductive logic are used in vary as it is in a common qualitative research. The writer will combine both verse from al-Qur'an and alHadith to determine whether the application of guarantee is proper or not. Then elaborate the analysis using Ușül al-Fiqh and Ușüliyah Law. After getting some points of clarity the data then compromised with the opinion of religious expert from a madhhab and contemporary. The writer expects this will give a great contribution among the academics and Muslims particularly.

\section{RESULTS AND DISCUSSIONS}

The word guarantee originated from an English word which means insurance (Shadily \& Echols, 1996, p. 282). In economic dictionary, guarantee is defined as a part of a deal in transaction (Poerwadarminta, 2007, p. 351), where the seller give insurance that the item sold is in good condition for certain length of time (Muda, 2003, p. 167).

In verse 1316 Civil Law Book, guarantee is a letter of notice from a product saying that the product is free of workers mistake and material failure in certain length of time. We may have 
come across many times with this kind of transaction enclosed with guarantee, especially those items of automotive and electronic. Guarantee is offered by producers or sellers to support effective marketing of a product with affordable standard. Basically, product that can be applied with guarantee can be classified as follow:

1. Simple product.

Usually producers are confidents in giving a full replacement if their product happened to be failure.

2. Middle-end product.

Guarantee in middle-end product has many varieties, some offers free service, free oil, free spare parts exchange, others even offer luxury facility such as air-conditioned room, music, free internet, free massage, snack etc where customers can relax and feel comfortable during repairmen process. Usually those are given under certain time, specific limit and so on as applied by automotive and electronic producers.

Al-Quran has given specific guidance about human interaction, especially one about transaction. Allah (peiH) spoke in the al-Mā idah, verse 1.

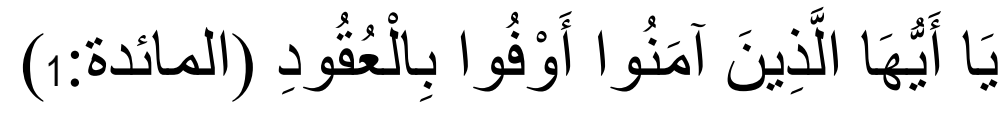

"O you who believe! Fulfill (your) obligations". (al-Mā̄idah, verse 1)

It can be concluded from the above verse that all mankind must keep promise in doing transaction ('aqd). The use of al-'Aqd is similar with the word al-'Ahd (promise). Both words have the same consequence and essential, that is responsibility of what have been agreed. Imam Ibn Haitim explained that the verse tells about the transaction between the Prophet pbuh with 'Ammār bin Hazm when the prophet sent him on a preaching mission.

According to lbn 'Abbās ra and Mujāhid, the expression al-Uqū $d$ has the same meaning as al-Uqu $\mathrm{d}$, which is doing transaction in a form of deal, sworn oath and others. Based on 'Alī bin Țalhah, means to be consistent and loyal with syariat regulations. While according to Zaid bin Aslam, manifestation of Awfū bi al-'Uqū $d$ comprise six aspects which are: agreement with God, 'aqd of half (Oath), 'aqd of shirkah (party), 'aqd of bay' (transaction), 'aqd of marriage and 'aqd of al-yamin (Ibn Kathīr, 1998, II, p. 3). QS. al-Nisā', verse 29.

In another verse Allah SWT stated standardize rule about ethic in social interaction, either the one concerns with transaction or how-to life. As stated by God in QS. An-Nisa verse 29:

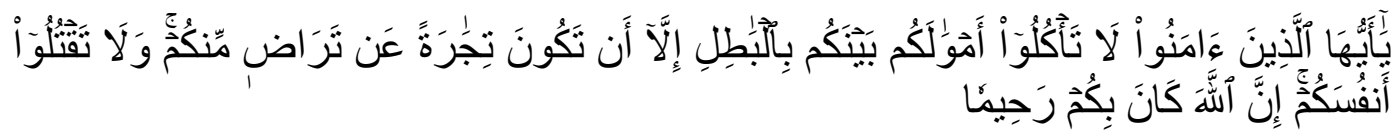

O you who believe! Eat not up your property among your selves unjustly except it be a trade amongst you, by mutual consent. And do not kill yourselves (nor kill one another). Surely, Allah is most Merciful to you" (QS. al-Nisā', verse 29)

The verse above explains about procedure of managing and the use of one's wealth for the good of all. The word "läta'kulü" can be interpreted as any ways of managing the wealth which usually confronted by al-battil. In this case the Ulama stated that the main purpose of wealth management is concern with the way the wealth used for consumptive reason which 
in the above verse expressed by lā ta'kulū. Meanwhile, the meaning of bāțil according to the verse is interpreted into two meanings, as explained below:

1. Every procedure that is not allowed by the syariat, such as ribā ghasb, stealing, cheating, corruption, bribing, false acquisition and others.

2. All wealth taken from other people without compensation, as stated by Ibnu Abbas ra and

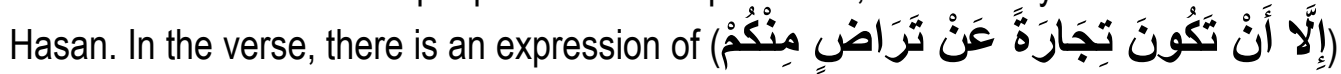
which rule every management and transaction that allowed by the person still considered legit according to sharia as long as it doesn't contradictive with the regulation apply (alRāzī, 2004, IV, p. 71).

In a transaction, sometimes there is some sort of agreement or request from one of the party involved. What should be questioned is whether the bond or agreement legitimate or not. As in Islam Law, freedom in doing transaction is respected as long as it is conducted based on the regulation. A transaction is not allowed under an intervention of other party outside the agreement. This goes back to the words spoken by the Prophet pbuh:

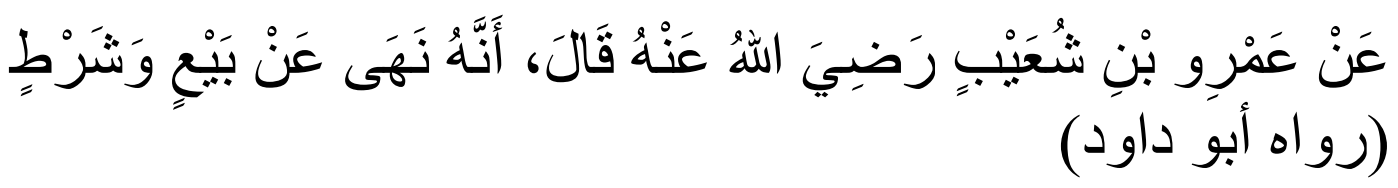

Translation:"Indeed Prophet Muhammad SAW prohibits the sale and purechase transactions with conditions" (Abū Dāwūd, 2009)

From that hadith, emerge the view of some ulama who think that bond in every transaction, especially the requirements of one side, whether the consumer or the producer is not justified, as the view among Shafi'iya. But some of them think that it is not problem in a transaction. They perceive that there are many other references that can be used as a guide on practices above, so it will not interfere the freedom of trade. This opinion is expressed by the majority of Hanabila (Hay`ah Kibār al-'Ulamā’ bi al-Mamlakah al-Su'ūdiyah, 2000, I, p. 280), especially for the opinions that expressed by Ibn Taymiyya and Imam Ibn al-Qayyim al-Jawziyya with based on the following hadith:

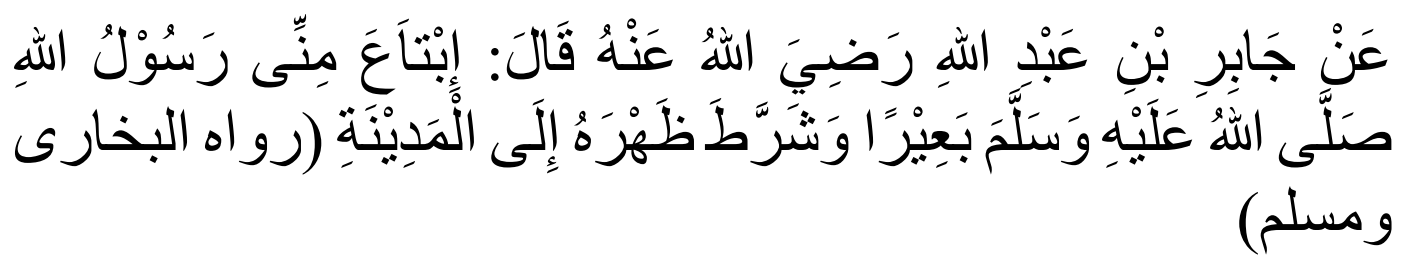

In fact, the Prophet Muhammad SAW had bought a camel to friend on a journey, he requires that the camels is able to take him him to Madinah". (Bukhārī, 2000; Muslim, 2012).

The reason they ask is that the legal origin of all bonds (condition) is allowed, either in the

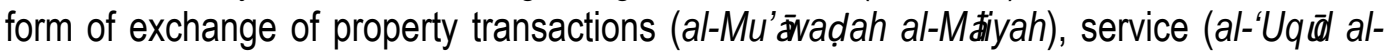
Tabarru'ah) as well as various forms of assurance (Naqvi, 2013, p. 20), both in general and specifically as it applies in Syirkah al-Ta'min (Insurance) and others (Swartz \& Coetzer, 2010). With a record it can give a positive effect on both sides. The legitimacy of the terms mentioned in this kind of transaction would have consequences that persons or parties who conduct a transaction have the authority to cancel (faskh) a transaction, if one party or side 
is unable to qualify promised. They may not agree on two kinds of bonds (requirements) are permitted, ie a condition which violates the basic principles and the terms of the transaction are prohibited by law or contradictive with law of Allah and His Messenger. The Prophet Muhammad pbuh once said:

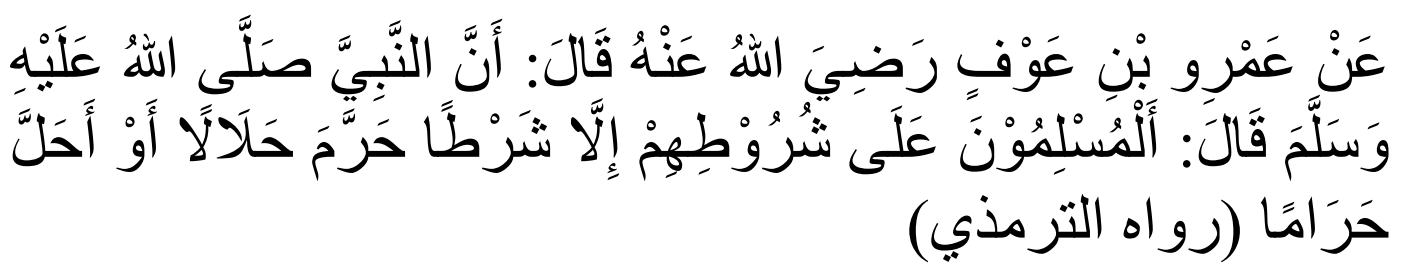

The Muslims are bound by the terms or covenants they proclaim, except the conditions forbidding the lawful and haraam halal'. (al-Tirmidhī, 2000)

Another version explains that sorting in the bond (terms) is required that occur within a transaction. Foundation of this question to arise is the hadith of Siti Aisyah ra that explaining the cancellation terms made by the Prophet, when Aisyah ra wanted to buy a slave named Barirah ra. From this hadith, they concluded that such transactions are still valid, but the terms that mentioned of the transaction is invalid (al-Māwardī, 1978, p. IV:382).

To compromise some opinions that exist, among Syafi'iyah and Hanafiyah try to distinguish the terms that occurs in the transactions into several categories (al-Zuhaylī, 1989, pp. IV:206-207). According Shafi'iyah requirements for a transaction can be divided into three parts:

1. The term that apply the basic principles of the transaction. For example, cash terms in the sale and purchase or on time terms in the rental. All of this will not affect the validity of the transaction, because the basic principles of transaction have determined it as an obligation before. Whereas the requirement is only to reinforce the emergence.

2. The terms related directly to the interest in the transaction. For example, the terms of determination period as assurance. Such requirement is not determined on the principle of the transaction, but on the basis of the requirements. But this term does not violate the rules in the transaction.

3. The terms that contrary with the basic principles of the transaction. le, any requirement that prevents consumers obtains his/her due or requires the seller to do something which is not their duty (al-Māwardī, 1978, p. IV:384; al-Zuhaylī, 1989, pp. IV:208-209).

Hanafiyah distinguish among these requirements in three categories, similar to the sorting of Shafi'iyah. Hanafiyah has also developed the practice of terms recognized on syariat but they offer braver terms from each category. As stated in the following conditions:

1. Al-Ṣahị term is the term that becomes a basic principal of transaction, recognized by syariat or practiced among the general (al-'Urf). According to them, this determination will give latitude. Because each of the terms is usually done by the public will get the recognition law, as long as it does not collide with the argument of Nash and do not violate basic principles of common law as well as common interests and goals.

2. Al-Fāsid term is other than those mentioned above. In the sense, does not mean the transaction charges, nothing that explains dalil syara even does not apply in the community. However, these terms still give benefit for the perpetrators of the transaction. 
According to them, the impact of this law is differentiated according to the type of transaction made. If it includes to al-Mu'äwadhah al-Mäliyah (exchange of property), then it could lead to invalidity of a transaction. But when it includes to transaction type of alTabarru'ät (free service) such as grants (provision) and borrowing ('ariyah) or in the form of al-Tautsiqah (collateral), as well as pawnshops (al-rahn), the transfer of liabilities (alhawālah) and deferred gurantee (al-kafälah), these terms have no bearing on the validity of a transaction, such terms are considered as not working.

3. Al-Bäțil term is every contract will be detrimental to either party. Regulation of transaction in which there is a legitimate term such this one is considered legal and the condition is considered void in law (al-Zuhaylī, 1989, pp. IV:209-210).

Islam in the context of mu'āmalah always puts precaution in any case containing contradictory sides between good and evil (Syaputra et al., 2014) through the general concept "Dar" al-Mafāsid Muqaddamun alāJalb al-Mașdih" (resist damage is a priority to conclude good). In a transaction issues, what we can do is to prioritize actions to minimize or prevent the practice of transactions that could potentially harm either party before stepping on the use of goods issue.

In this context, the Ulama try to compromise verses relating to transaction, as the explanation contained in the verse of al-Qur'an and al-Hadith above, which then explained. In al-Qur'an and al-Hadith there are only mentiond 2 conditions of validity of guarantee in transaction. Explanation as follows:

1. The willingness (pleasure) each party.

2. The desire (endeavor), it means that the desire under normal circumstances, it is no element of coercion and should be with full awareness (al-Zuhaylī, 1989, p. IV:199).

Some mujtahid considers that the essence of the transaction is returned to the presence or absence of the willingness of each party. But another version reacts with choice form, especially when the transaction is no longer representative.

There are significant differences between things that relating to the worship and matters relating to mu'amalah. On problem of ubudiyah should be based on the dalil syara' '(wurud al-Shar'iy) directly. It means that there must be texts (al-Qur'an and al-Hadith which describe all aspects, types, procedures of the implementation and other condition of worship, should not create their own models or formulas. On the other hand, matters related to the mu'amalah should not reflect on the existence of verse law that explain the law concretely as in the case of sale and purchase transactions or guarantee. So, it is allowed to make any kind of transaction and in any way as it does not conflict with Syara'. Because it should be understood that the origin of everything is allowed as long as no law that forbid it (al-Zuhaylī, 1989, p. IV:200).

In this context, every ulama Madhhab try to explain the problems of warranties/guarantees and addressing the problems with the following explanation:

1. As-Syafi'i, he is addressing that the condition in guarantee forms, such as guarantees or other forms is not allowed, because there are a hadits that leads to this issue directly, that hadits determine that any bonds or interests that had nothing to do with the purpose of the transaction is forbidden. Nevertheless, among Syafi'iyah there are differences of 
opinion, partly prohibit and partly allow because there is a benefit to both producers and consumer (al-Zuhaylī, 1989, p. IV:2001).

2. Al-Hanafiyah, the view of ulama Hanafiyah is more focused on agreement factor and tradition as a barometer of the legality of a bond or interest in the transaction, as guarantee, when it is agreed or trade tradition, so it can be allowed (al-Zuhaylī, 1989, p. IV:2016).

3. Al-Hanabilah, in this case ulama Hanabilah only see from one side, which is allowing the guarantee to be considered a new transaction that accompanies the purchase. But to allow this transaction as aqad ijarah/ rent still needs further discussion (al-Zuhaylī, 1989, pp. IV:208-209).

In the author's view the contract is included in the terms of the terms of sale and purchase. Khiyar conditions are the voting rights that are set for one of the parties who are conscious or both or for another person to continue or cancel the sale and purchase, as long as it is within the specified time period. For example, the buyer says: "I bought goods from you on the condition that I have the right to choose between continuing or canceling the sale transaction if something goes wrong". As was done by the Apostle in one of his words: "In fact, the Prophet Muhammad SAW had bought a camel to friend on a journey, he requires that the camels are able to take him him to Madinah". (al-Bukhārī and Muslim). The reason they ask is that the legal origin of all bonds (condition) is allowed, either in the form of exchange of property transactions (al-Mu'âwadah al-M Jijyah), service (al-'Uqül alTabarru'‡) as well as various forms of assurance, both in general and specifically as it applies in Syirkah al-Ta'min (Insurance) and others. With a record it can give a positive effect on both sides.

The legitimacy of the terms mentioned in this kind of transaction would have consequences that persons or parties who conduct a transaction have the authority to cancel (faskh) a transaction, if one party or side is unable to qualify promised. They may not agree on two kinds of bonds (requirements) are permitted, ie a condition which violates the basic principles and the terms of the transaction are prohibited by law or contradictive with law of Allah and His Messenger.

\section{Tarjīh/Weighting}

1. On the guarantee law, writer prefers the opinion of the majority of Syafiiyah, Hanafiyah and Hanabilah stating that the sale of the legal guarantee is valid because there is the benefit.

2. The inclusion of guarentee in the buying and selling just as promise (al-Wa'd) from manufacturer or seller to the consumer or purchaser or simply the service provided to the buyer so that they feel satisfied.

3. Consequences, if the item is broken in the hands of the buyer, the seller must replace it (al-Khar bi al-Dam剓) but keep in view the type of damage. 


\section{CONCLUSION}

The difference of opinion among ulama about the legality of the practice guarantee in the sale and purchase transaction is simply due to differences in the basis of the legal decision. Where the Syafi'iyah assumes that this kind of transaction model is not valid because there are a dalil that leads to prohibit enclosing on the sale and purchasing transactions. But some of ulama Hanafiyah, Hanabilah and Syafi'iyah prefer to allow the practice of buying and selling that is accompanied with a guarantee because they are more focused on the agreement factors and traditions as a barometer of the legality/validity of a bond or interest in the transaction. As well as the guarantee, when it is agreed or it is a tradition in the trade, then according to their opinion it is allowed.

\section{Refferences}

Abdul-Rahman, Y. (2014). The Art of RF (Riba-Free) Islamic Banking and Finance: Tools and Techniques for Community-Based Banking (2nd edition). Hoboken: Wiley.

al-Jurjānī, 'Alī. (1980). al-Ta'rîfāt. Dār al-Kutub al-'Arabiyah.

al-Māwardī, A. al-Ḥasan. (1978). al-Ḥ̄̄wī al-Kabīr. Bayrūt: Dār al-Fikr.

al-Rāzī, F. al-Dīn. M. ibn 'Umar. (2004). al-Tafsīr al-Kabīr aw Mafatīh al-Ghayb. Bayrūt, Lubnān: Manshūrāt Muhammad 'Alī Bayḍūn.

al-Tirmidhī, M. ibn 'T̄sā. (2000). Sunan al-Tirmidhī. Vaduz, Liechtenstein : Jam'iyat alMaknaz al-Islamī,.

al-Zuhaylī, W. (1989). al-Fiqh al-Islāmī wa Adillatuh. Dimashq: Dār al-Fikr.

Askari, H., Iqbal, Z., \& Mirakhor, A. (2014). Introduction to Islamic Economics: Theory and Application. Singapore: Wiley.

Bachtiar, W. (1997). Metodologi Penelitian IImu Dakwah. Jakarta: Logos.

Bogdan, R., \& Taylor, S. J. (1975). Introduction to qualitative research methods: a phenomenological approach to the social sciences. New York: Wiley.

Bukhārī, M. ibn Ismā'̄̄l. (2000). Șaḥịh al-Bukhārī. Liechtenstein: Jam'iyat al-Maknaz alIslami.

Canavor, N. (2013). Business Writing For Dummies. Chichester: John Wiley \& Sons.

Essid, M. Y. (1995). A Critique of the Origins of Islamic Economic Thought. Leiden: BRILL.

Fiore, C. (2003). Lean Strategies for Product Development: Achieving Breakthrough Performance in Bringing Products to Market. Wisconsin: ASQ Quality Press. 
Gabszewicz, J. J. (1999). Strategic Interaction and Markets. New York: Oxford University Press.

Hay’ah Kibār al-'Ulamā’ bi al-Mamlakah al-Su'ūdiyah. (2000). Abhāth Hay'ah Kibār al'Ulamā.' Bayrūt: Dār lhyā̄' at-Turāth al-'Arabī.

Holder, J. (2016). Stop Wasting Money on Ineffectual Marketing. n.p.: Iulu.com.

Ibn Kathīr, I. ibn ‘Umar. (1998). Tafsīr al-Qur’ān al-'ażīm. Mu’assasat Qurțubah.

Muda, A. A. K. (2003). Kamus Lengkap Ekonomi. Jakarta: Gitamedia Press.

Muhadjir, N. (2000). Metodologi Penelitian Kualitatif (4th Edition). Yogyakarta: Rakesarasin.

Muslim. (2012). Șahịḥ Muslim. Bayrūt : Dār Ibn Ḥazm.

Naqvi, S. N. H. (2013). Islam, Economics, and Society (1 edition). London: Routledge.

Poerwadarminta, W. J. S. (2007). Kamus Umum Bahasa Indonesia (3rd ed.). Balai Pustaka.

Shadily, H., \& Echols, J. M. (1996). Kamus Inggris - Indonesia. An English - Indonesian Dictionary (Cet. 23). Jakarta: PT Gramedia Pustaka Utama.

Sigman, H. C., \& Kieninger, E.-M. (Eds.). (2009). Cross-border security over receivables. Munich: Sellier European Law Publishers.

Swartz, N. P., \& Coetzer, P. (2010). Takaful: An Islamic insurance instrument. Journal of Development and Agricultural Economics, 2(10), 333-339.

Syaputra, E., Hilal, F. N., Febriansyah, M., Qaed, I., Amiruddin, M. M., \& Aziz, M. R. A. (2014). Maslahah as an Islamic Source and its Application in Financial Transactions. Quest Journals Journal of Research in Humanities and Social Science, 2(5), 66-71.

Thompson, J. L., \& Martin, F. (2005). Strategic Management: Awareness, Analysis and Change (5th edition). London: Cengage Learning. 